\title{
Marine magnetic investigation of the submarine base of Mt. Etna and Hyblean Plateau
}

\author{
Ciro Del Negro $\left({ }^{1}\right)$, Fabrizio Ferrucci $\left({ }^{2}\right)$ and Rosalba Napoli $\left({ }^{1}\right)$ \\ ${ }^{(1)}$ Istituto Nazionale di Geofisica e Vulcanologia, Sezione di Catania, Italy \\ ${ }^{2}$ ) Dipartimento Scienze della Terra, Università della Calabria, Arcavacata di Rende (CS), Italy
}

\begin{abstract}
Two marine magnetic surveys were carried out during 1997 and 1999 in the Ionian Sea off the eastern coast of Sicily to investigate the magnetic structures of the eastern base of Mt. Etna and the Hyblean Plateau. The investigated area is approximately $85 \mathrm{~km}$ long and $15 \mathrm{~km}$ wide, running from North to South, in the Western Ionian Sea. Models along two profiles parallel to the coast and over the entire area provide a possible distribution of volcanic bodies and volcaniclastic deposits off the eastern coast of Sicily and their relations with the sedimentary substratum. 3D modeling suggests the presence of magnetized bodies, inserted in the sedimentary substratum, plausibly related to Hyblean Plateau volcanism in the south sector and to Mt. Etna activity in the north. We speculate that the Malta Escarpment could have produced preferential ways for magma ascents off the Hyblean Plateau. The spatial continuity of the volcanism affecting the entire investigated area could testify spatial transition between Hyblean and Etnean volcanism supporting the hypothesis that the magma process migrated with time from south-east to north-west.
\end{abstract}

Key words magnetic survey - magnetic modeling Mt. Etna - Hyblean Plateau

\section{Introduction}

The geological and structural frame of Sicily is the result of complex motions and interactions between the African and European plates, which have produced, in the Mediterranean region, the Calabro-Sicilian subduction process (Barberi

Mailing address: Dr. Rosalba Napoli, Istituto Nazionale di Geofisica e Vulcanologia, Sezione di Catania, Piazza Roma 2, 95123 Catania, Italy; e-mail: napoli@ct.ingv.it et al., 1974; Lentini, 1982). In this context, Eastern Sicily represents the connection area between the Maghrebian-Calabrian thrust belt (European plate), which occupies the northern part of Sicily (fig. 1), and the African foreland, whose leading edge, the Hyblean Plateau, crops out in the southeastern corner of the island (Grasso et al., 1983; Grasso and Ben-Avraham, 1992; Hirn et al., 1997). The Hyblean Plateau is cut off along the eastern coast by a regional fault system, the Malta Escarpment, which splits it from the thinned oceanic crust of the Ionian basin (Grasso et al., 1983; Monaco et al., 1995). Within this general compressional tectonic framework, an intense basaltic volcanic activity has intermittently affected Eastern Sicily for $200 \mathrm{Ma}$ (Patacca et al., 1979; Hirn et al., 1997). This activity, related 


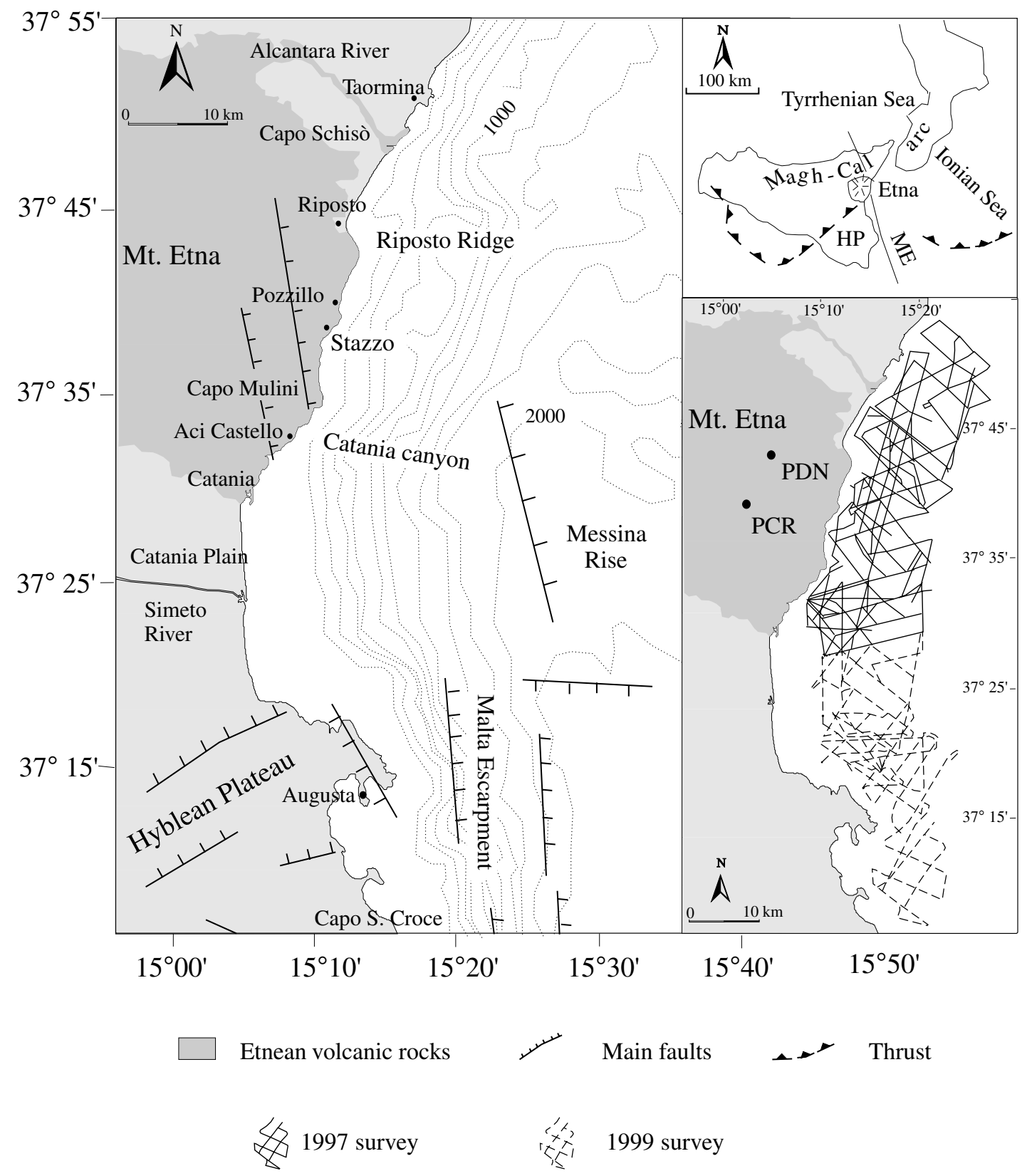

Fig. 1. Simplified tectonic map of the eastern coast of Sicily. The insets at the right show: at the top the relative position of the Hyblean Plateau (HP), the Malta Escarpment (ME) and the Maghrebian-Calabrian thrust belt (Magh-Cal arc); at the bottom the investigated area in 1997 and 1999. Lines represent measurement tracks. 
to different episodes of local extensional tectonics (Barberi et al., 1974; Grasso and BenAvraham, 1992), is responsible for the volcanism of both the Hyblean Plateau and Etna. They have been connected to extensional processes, with WNW-ESE trend, orientated along a rifting zone, which develops from the Hyblean Plateau to Northern Calabria (Tapponnier, 1977; Tortorici et al., 1986; Monaco et al., 1995). In particular, marine seismic profiles executed by Hirn et al. (1997) reveal how Etna appears structurally linked to an extensional domain reaching offshore from Catania and Augusta.

Considering that the structures held accountable for the Hyblean and Etnean volcanism develop partly offshore along the border of a continental scarp, it is likely that most of the products representing their geological and volcanological evolution are submerged along the eastern Ionian coast of Sicily. Marine geological and geophysical investigations, therefore, may represent a useful tool to support and integrate data gathered inland to improve the knowledge of both the Hyblean Plateau and Etna evolution. Since the early 1990s, the area off the eastern coast of Sicily has been studied intensively, including two oceanographic campaigns promoted by the Italian Consiglio Nazionale delle Ricerche in 1997 and 1999. Magnetic data as well as seismic and bathymetric data, integrated by drags and cores to investigate seafloors to a depth of about $2000 \mathrm{~m}$, were collected during these survey cruises.

This paper focuses on the analysis of magnetic data gathered along a more than 500 $\mathrm{km}$ line. Their interpretation, in combination with previous geological and geophysical studies (e.g., Gabbianelli et al., 1995), evidences the offshore prosecution of the Etnean edifice and the area affected by magmatism off the Hyblean coast. The presence of volcanic bodies, and especially their prosecution southwards to the main faults of the Malta Escarpment, could represent the spatial transition between Hyblean and Etnean magmatism and highlights the major role played by the regional discontinuities in the spatial and temporal evolution of the PlioPleistocene volcanism of Eastern Sicily.

\section{Morphological and structural framework}

The submerged area off the eastern coast of Sicily (fig. 1) is characterized by a $900 \mathrm{~m}$ wide continental platform related to the last glacialeustatic cycle which reached its maximum regression about $18 \mathrm{Ka}$ BP (Gabbianelli et al., 1995). It develops parallel to the coast reaching variable depths (160-80 m) and joins the emerged zone and continental scarp. The latter, whose mean width is $17 \mathrm{~km}$, is characterized by average inclinations of $4-6^{\circ}$ and extends offshore to a depth of 1800-2000 m (Bousquet et al., 1998) where it is replaced by the Messina Rise, a large sector of the Ionian basin with a NNW-SSE direction which represents a fragment of the Hyblean Plateau which collapsed after the middle Pleistocene (Sartori et al., 1991).

The northern part of the investigated area (fig. 1) is dominated by the Riposto Ridge, a morphological lineament about $20 \mathrm{~km}$ long and $4 \mathrm{~km}$ wide, which reaches a depth of about $1500 \mathrm{~m}$ with an E-W trend. The Riposto Ridge, made of sedimentary substratum and affected by compressive structures, could represent the offshore prosecution of the units of the Maghrebian-Calabrian chain (Gabbianelli et al., 1995; Del Negro and Napoli, 2002). It is bounded to the north by a canyon while to the South the seafloor shows an irregular morphology up to the Canyon of Catania, a large depression extended off Acicastello (Bousquet et al., 1998) and bounded southwards by the Catania Plain (Rossi and Sartori, 1981). The area off the Etnean edifice is also affected by the presence of NS and NNW-SSE striking normal faults, which could be the offshore prosecution of the Timpe system (Sartori et al., 1991; Lanzafame and Bousquet, 1997). These faults appear as segments at least 20-30 km long stretching from Etna southwards and reaching offshore from Catania and Augusta (Hirn et al., 1997). These long faults define some Pleistocene extensional basins which are isolated from each other by shorter faults oriented ENE-WSW and NE-SW. Some of them seem to represent the continuation of the main faults, which affect the Hyblean inland area (Sartori et al., 1991). Moreover, the offshore area of Augusta is characterized by the presence of the northern part of the Malta Escarpment whose morphologic drop is greater than $2000 \mathrm{~m}$ (Sartori et al., 1991). 


\section{Magnetic survey}

Digital magnetic data were gathered simultaneously with bathymetric data during two cruises of R/V Urania in 1997 and 1999. Firstly, the area between Taormina and Catania along the eastern coastal side of Mt. Etna was surveyed, and subsequently the area between Catania and Capo S. Croce off the Hyblean coast (fig. 1). The data acquisition array was irregular, with the mesh ranging between 1 and $3 \mathrm{~km}$. The whole area is placed in the Western Ionian Sea between $37^{\circ} 07^{\prime} 00^{\prime \prime} \mathrm{N}-37^{\circ} 53^{\prime} 00^{\prime \prime} \mathrm{N}$ and $15^{\circ} 08^{\prime} 00^{\prime \prime} \mathrm{E}$ $15^{\circ} 26^{\prime} 00^{\prime \prime} \mathrm{E}$ and is approximately $85 \mathrm{~km}$ long and $15 \mathrm{~km}$ wide. A Geometrics G-811 proton precession magnetometer, with $1 \mathrm{nT}$ resolution, was used to make measurements of the total intensity of the Earth's magnetic field. The sensor was dragged at $23 \mathrm{~m}$ below sea level by a steel cable about $300 \mathrm{~m}$ long to reduce the magnetic effects of the ship. We connected the sensor tip to a glass fiber ring to reduce possible sharp movements, oscillations or rotations produced by waves and currents. We collected about 100000 readings at $5 \mathrm{~s}$ intervals, which is equivalent to a distance of approximately $10 \mathrm{~m}$ at the cruising speed of about 4 knots. Positioning relied upon the GPS (Global Positioning System) differential system, with base station located on shore at Catania. Moreover, a gyrocompass defining the direction of navigation allowed to correct the offset error related to the distance between the magnetic sensor and the ship.

The magnetic surveys were carried out nighttime to minimize the effect of the solar activity. Moreover, surveying was usually done during magnetically quiet days when the values of the magnetic activity $K$ index were generally less than 1 (from J.D. 129:1997 to J.D. 133:1997, J.D. 21:1999, from J.D. 25:1999 to J.D. 26:1999 and from J.D. 31:1999 to J.D. 33:1999). Strict control of the level temporal variations was obtained using data continuously recorded at stations of the permanent network for magnetic monitoring of Mt. Etna (Del Negro et al., 1997). During the marine cruises, only these stations were working. PCR and PDN stations were the most suitable for use as reference stations since they are located a few kilometers apart westward from the center of the investigated area (fig. 1).
Measurements of the total intensity field, collected every minute at PCR (in 1997) and PDN (in 1999), have thus been used to correct data for the diurnal variation. To compute the magnetic anomalies and apply secular variation correction, data reduction process included removal of the Earth's magnetic field using the IGRF reference fields of the corresponding periods (IAGA Division V, Working Group 8, 1996). Once the anomaly values were obtained, the magnetic data of each survey were adjusted to minimize discontinuities in the overlap regions (Ishihara et al., 1999). The standard deviation of crossover differences was $83 \mathrm{nT}$ for the uncorrected data, but is reduced to $35 \mathrm{nT}$ by applying a constant bias to each cruise. Finally, the data from these two surveys were merged to provide only one data set for the entire area. In order to prepare a contour map, the corrected data were gridded at a spacing of $0.5 \mathrm{~km}$ using a minimum curvature algorithm. The anomaly magnetic field, which is shown in fig. 2, appears particularly complex close to the coast where several anomalies with different intensity and extension were detected. Taking advantage of the very close sampling step adopted $(10 \mathrm{~m})$ with respect to the real resolution of the survey (some kilometers) a low-pass filter, with a cutoff wavelength of $3 \mathrm{~km}$ was applied to reduce high frequency noise and to enhance the effects of deepseated bodies or broad shallow sources. The cut off frequency was established using a one-dimensional spectral procedure, less representative of the fields but more stable than the radial spectral procedure which is often affected by a migration phenomenon of minimum amplitude spectral points (Faggioni et al., 2001). The resulting filtered magnetic map is shown in fig. 3 . The general trend is not well correlated with the published magnetic anomaly map of Italy and surrounding seas (Chiappini et al., 2000). High anomalies with short wavelength and large amplitude, which do not appear on the published map, were observed. The northern part of the area is characterized by a wide anomaly located off the coast between Stazzo and Capo Schisò. Southwards, two more intense and well defined anomalies were detected respectively in correspondence of the Capo Mulini and Aci Castello lava flows and south of Catania very close to Augusta. Each of these anomalies disappears offshore at $10-20 \mathrm{~km}$ from the coast. 


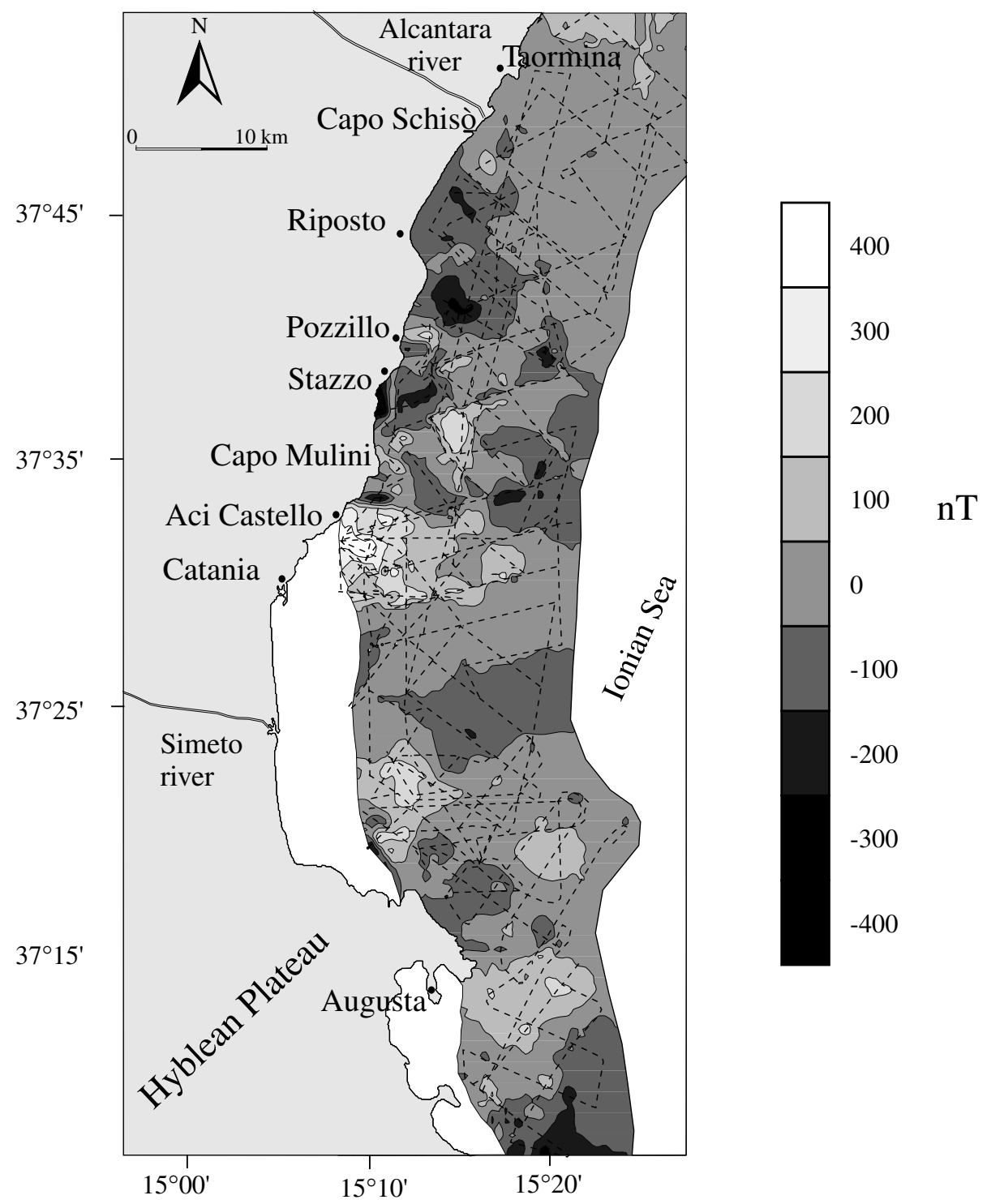

Fig. 2. Map of the total intensity magnetic field. Dotted lines represent magnetic measurements.

\section{Modeling}

To obtain a picture of the sources of the magnetic anomalies we calculated models along two profiles parallel to the coast $\left(\mathrm{AA}^{\prime}\right.$ and $\left.\mathrm{BB}^{\prime}\right)$ and then over the whole surveyed area (fig. 3).
The modeling procedure was carried out by a 3D program (Potent v3.06 produced by PC Potentials, Australia), which adjusts the model using a combination of manual (forward modeling) or automatic (inversion modeling) commands until it achieves a satisfactory fit. 


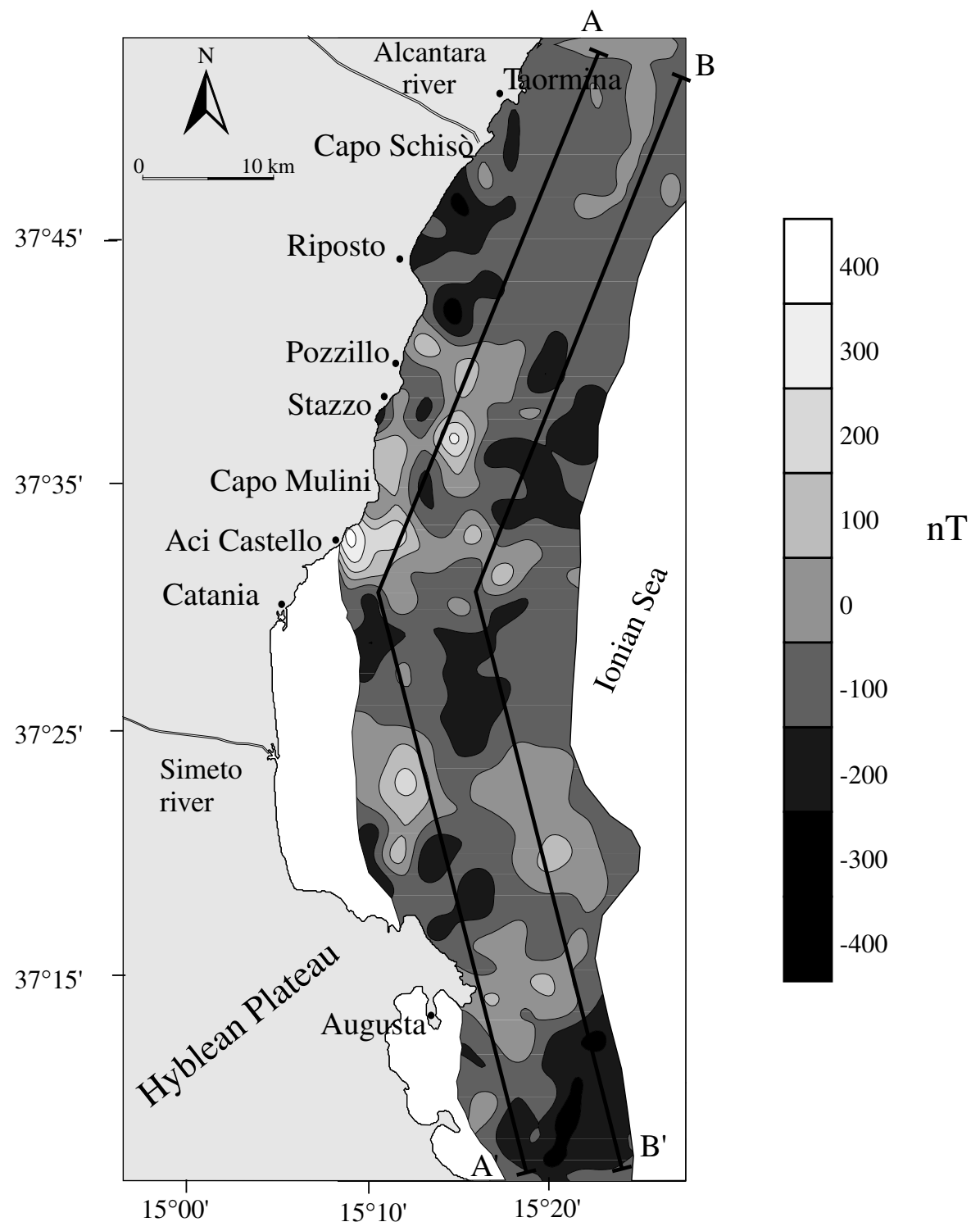

Fig. 3. Low-pass filtered magnetic map of the investigated area. The cutoff wavelength is $3 \mathrm{~km}$. Black lines (AA' and $\mathrm{BB}^{\prime}$ ) represent modeled profiles.

Potent calculates magnetic anomalies by assuming that the source bodies are 3D prisms, both rectangular and polygonal, with uniform magnetization. In particular, the magnetic effect of a $3 \mathrm{D}$ rectangular prism is calculated using a formula derived along lines similar to those of Bhattacharyya (1964). The calculation for the magnetic effect of a 3D polygonal prism is programmed in two stages. Firstly, two orthogonal field components normal to the axis of 
the prism are calculated using formulas derived along the same lines as those given by Cady (1980) for the gravity case. Subsequently, the component along the third axis of the prism is evaluated using a numerical integration. This increases the calculation time considerably, but the field calculation is exact at any point external to the $3 \mathrm{D}$ polygonal prism.

\subsection{Rock magnetic properties}

No direct measurements of remanent magnetization $\left(J_{\mathrm{NRM}}\right)$ and susceptibility $(\chi)$ are available for rock samples offshore Eastern Sicily. Therefore, we decided to infer most of $J_{\mathrm{NRM}}$ and $\chi$ values by comparison with petrographically similar rocks, even though petrographic similarity does not constrain complete magnetic similarity (the latter relates also to other factors including the history of each rock). However, unless severe geo-statistical rules are observed, laboratory data obtained from a few samples within a single outcrop would also undergo the same error (Fleming and Tréhu, 1999).

Since the chemical composition of dragged rocks matches quite well with the compositional range known for Etnean and Hyblean products outcropping along the Ionian coast (Pompilio, personal communication), we used the results of laboratory tests carried out on several samples of lava flows, volcaniclastic deposits and alluvium collected in the south eastern Sicily (Roberti and Scandone, 1975; Tabacco, 1998; Del Negro and Napoli, 2002). These measurements reveal a magnetization mean value of $7 \mathrm{Am}^{-1}$ and a susceptibility mean value of 0.034 S.I. for lava flows. Instead, volcaniclastic deposits and alluvium display lower values of $J_{\mathrm{NRM}}$ (between 2 and $3 \mathrm{Am}^{-1}$ ) and $\chi$ (between 0.01 and 0.02 S.I.). Therefore, we assumed the volcaniclastic deposits and volcanic rocks to have values of $J_{\mathrm{NRM}}$ and $\chi$ ranging respectively between 2 and $7 \mathrm{Am}^{-1}$ and between 0.01 and 0.034 S.I., whereas we have assumed the sedimentary basement to have no magnetization. These initial model values required little subsequent modification to provide a reasonable match to the magnetic data. Inclination $(I)$ and declination $(D)$ of remanent magnetization were set equal to that of the present-day Earth's field. This assumption is justified by the observation that the area northwards of the Simeto River is mainly characterized by Etnean products (about $0.5 \mathrm{Ma}$; Gillot et al., 1994) which show a remanent magnetization generally much greater than induced magnetization (Königsberger ratio is $>1$; see e.g., Rolph, 1992; Tric et al., 1994) and which were emplaced after the last field reversal $(0.78 \mathrm{Ma}$; Tauxe et al., 1992). On the other hand, also for the Hyblean area, which is characterized by volcanic rocks emplaced before the last field reversal (200 Ma ago; Patacca et al., 1979; Hirn et al., 1997), susceptibility values calculated by Arisi Rota and Fichera (1987) tend to exclude the remanent magnetization oriented in a direction not parallel to the present magnetic field, even in the opposite direction. In particular, we obtain the best result assigning to inclination and declination the values obtained by IAGA (1996) for the IGRF 1995 field (approximately $\left.I=52^{\circ} \mathrm{N}, D=1^{\circ} \mathrm{W}\right)$.

Since we have few constraints on the detailed crustal structure of the investigated area, the geometry and position of each body were estimated from the isolated magnetic anomaly patterns and varied until the RMS error between the observed and calculated data was less than $20 \mathrm{nT}$ for profiles and $100 \mathrm{nT}$ for whole area. The bathymetric data collected simultaneously with the magnetic measurements were used to define sea bottom topography.

\subsection{Profile $A A^{\prime}$}

The first profile (AA'), about $80 \mathrm{~km}$ long, runs near the coast from Taormina to Augusta and consist of two parts NNE-SSW and NNW-SSE orientation, respectively. The geological outline obtained by the modeling is described below and illustrated in fig. 4. The wide anomaly located between Stazzo and Capo Schisò off the main outcrop inland of the Chiancone deposit (Del Negro and Napoli, 2002) is modeled as a single body (A1) about 12-14 km long and outlined up to a depth of about $800 \mathrm{~m}$ under the sea level. The mean thickness of $\mathrm{A} 1$ is about $200 \mathrm{~m}$ and its magnetic properties $J r=3 \mathrm{Am}^{-1}$ and $\chi=0.01$ S.I. intermediate between lava products and 
Ciro Del Negro, Fabrizio Ferrucci and Rosalba Napoli

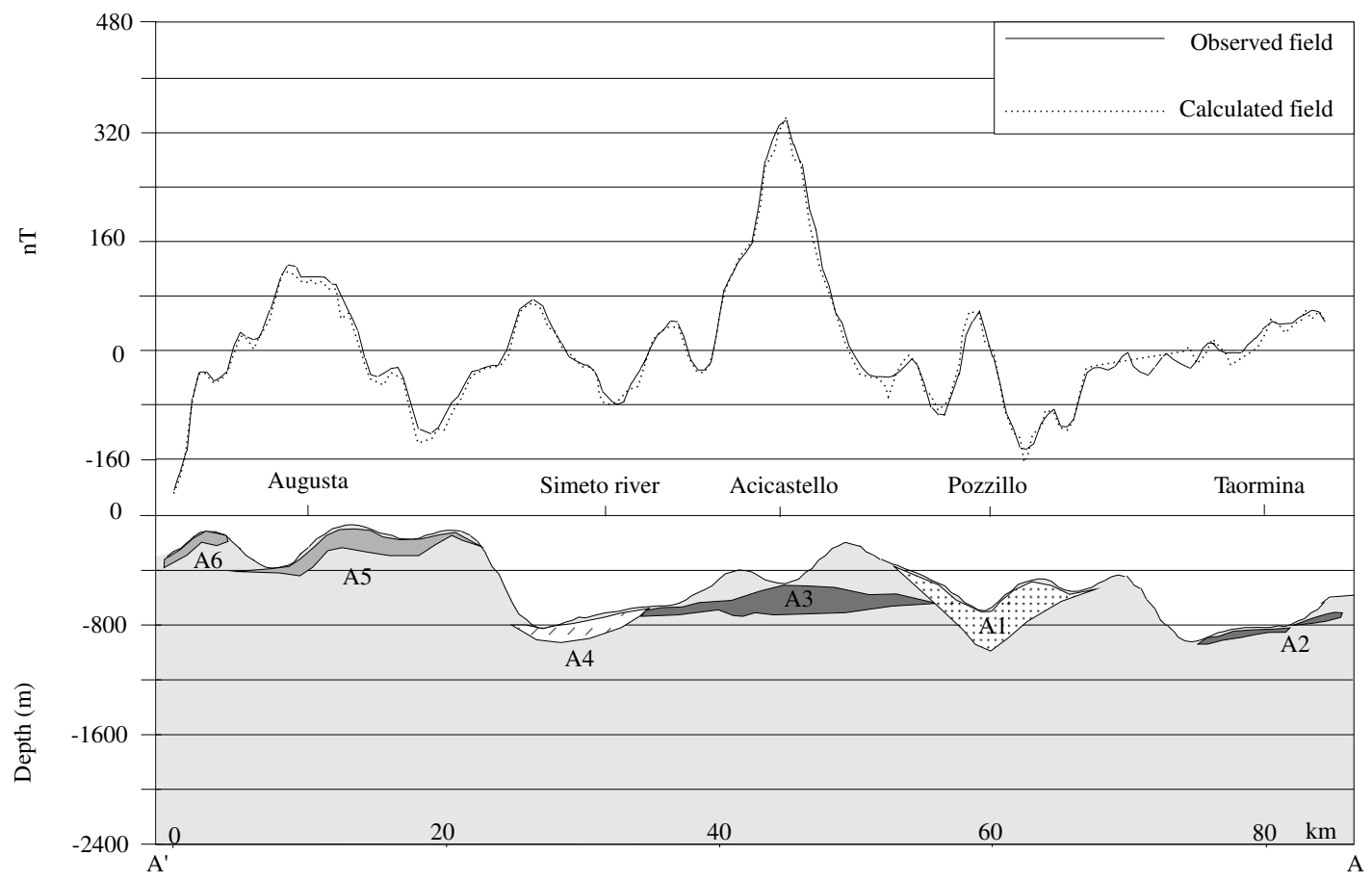

Magnetic properties

\begin{tabular}{|c|c|c|}
\hline & Sedimentary substratum & $\chi=0.00$ S.I. $\quad \mathrm{J}_{\mathrm{NRM}}=0 \mathrm{~A} / \mathrm{m}$ \\
\hline & Hyblean volcanic rock (A5 and A6) & $\chi=0.03$ S.I. $\mathrm{J}_{\mathrm{NRM}}=4 \mathrm{~A} / \mathrm{m}$ \\
\hline 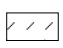 & Volcaniclastic deposit (A4) & $\chi=0.01$ S.I. \\
\hline & (A3 and A2) & $\chi=0.034$ S.I. $\mathrm{J}_{\mathrm{NRM}}=5 \mathrm{~A} / \mathrm{m}$ \\
\hline 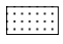 & Chiancone deposit & $\mathrm{J}_{\mathrm{NRM}}=3 \mathrm{~A} / \mathrm{m}$ \\
\hline
\end{tabular}

Fig. 4. Magnetic modeling of profile $\mathrm{AA}^{\prime}$. At the top observed data compared to the modeled anomalies; at the bottom the geological models from which the modeled anomalies were computed.

sedimentary basement are referable to the Chiancone outcropping with a fan morphology spreading from the outlet of the Valle del Bove to the Ionic coast (Calvari and Groppelli, 1996). Northwards A 1 is replaced by the sedimentary basement which is overlaid at Taormina by a thin lava coverage (A2) referable to the Alcantara lava flows. The more intense anomaly located in the middle of the profile at Capo Mulini is well modeled as a $100-150 \mathrm{~m}$ thick lava body, $J r=5 \mathrm{Am}^{-1} \chi=0.034$ S.I. (A3). It underlies the sedimentary basement and stretches, growing thinner, both northwards up to the Chiancone, and southwards beyond Catania. A3 is bounded southwards by a volcaniclastic deposit (A4), which spreads for about $8 \mathrm{~km}$ south of Catania to the mouth of the Simeto River. Considering its location and its magnetic properties $J r=3 \mathrm{Am}^{-1}$ and $\chi=0.01$ S.I., the same as A1, it is reasonable to assume that A4 


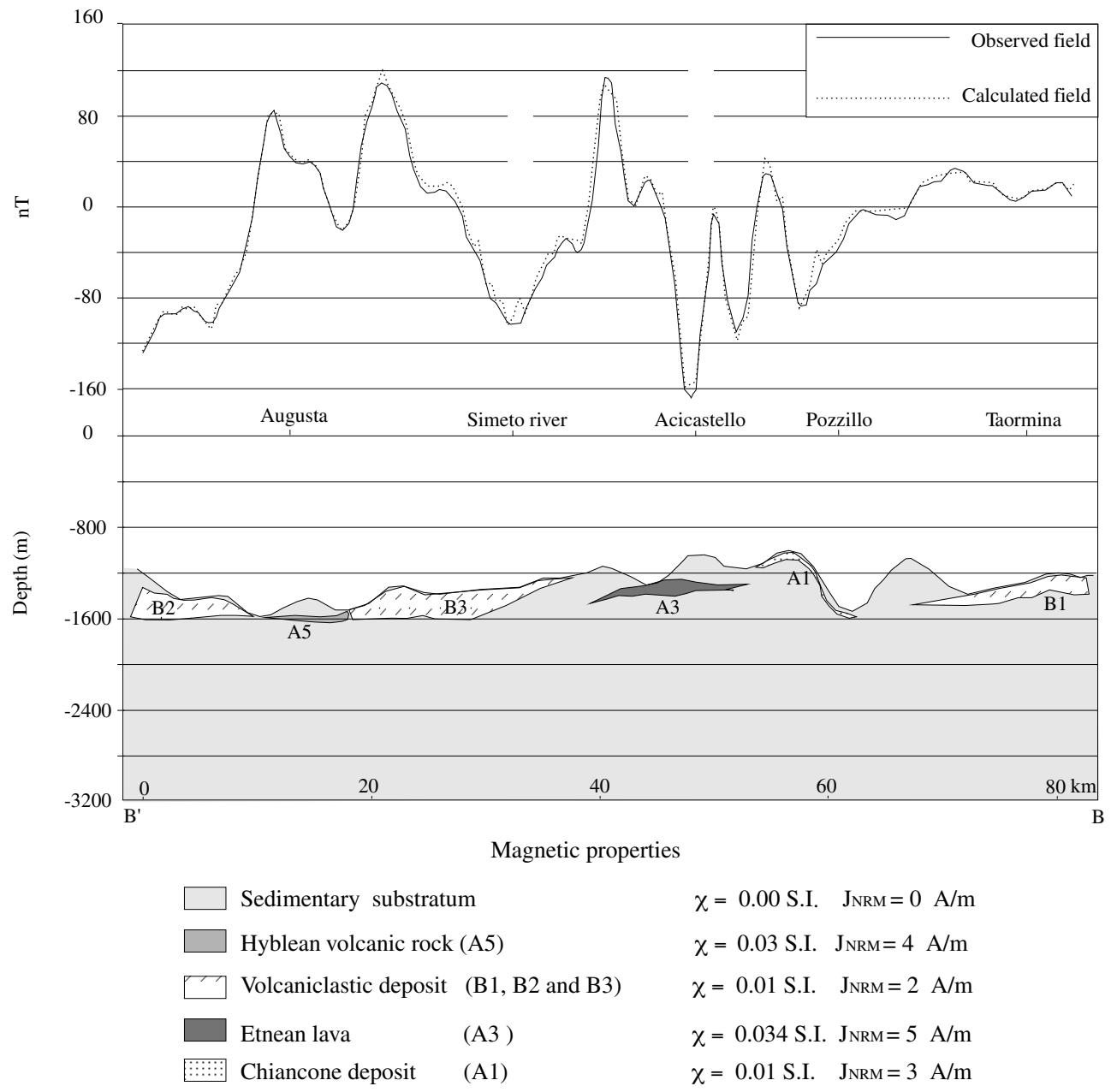

Fig. 5. Magnetic modeling of profile $\mathrm{BB}^{\prime}$. At the top observed data compared to the modeled anomalies; at the bottom the geological models from which the modeled anomalies were computed.

is formed by incoherent volcanic material sprung from dismantling of the volcanic outcrops on the western flank of Etna, and subsequently carried away and settled at sea by the Simeto River.

At the southernmost tip of the profile very near to Augusta two $100 \mathrm{~m}$ thick lava coverages (A5 and A6) 15 and $6 \mathrm{~km}$ long respectively were discovered. A susceptibility contrast of 0.03 S.I. between the volcanic products and the underlying sedimentary basement is assumed.

\subsection{Profile $B B^{\prime}$}

Another profile (BB'), parallel to the former and about $5 \mathrm{~km}$ away from it, was selected and modeled. Also this profile, like the $\mathrm{AA}^{\prime}$ profile, consists of two parts (fig. 3) and its schematic geological cross-section is shown in fig. 5. A considerable decrease in both extension and in thickness of the volcanic structures described in profile $\mathrm{AA}^{\prime}$ is evident, probably due to the great 
distance from the origin and/or derivation area. In particular, the volcanic bodies (A3 and A5) identified at Capo Mulini and Augusta preserve their magnetic characteristics unaltered and show a mean thickness less than $100 \mathrm{~m}$ and an extension of about 12 and $8 \mathrm{~km}$ respectively. The thin lava coverage (A2) related to the Alcantara lava flows at the northernmost end of the profile is replaced by a deposit (B1) whose magnetic properties $J r=2 \mathrm{Am}^{-1}$ and $\chi=0.01$ S.I. are similar to those of the Chiancone but is not ascribable to it. As for the Chiancone (A1), its extension is reduced to $8 \mathrm{~km}$ with a minimum thickness. Other volcaniclastic deposits (B2 and B3) are observed to the south and north of Augusta probably originated by accumulation driven by marine currents of volcanic products belonging to lava outcrops, which are present at the most proximal areas.

\subsection{Entire area}

On the basis of the schematic geological cross-sections described above, we produced a 3D forward model of the entire area. Since the magnetic anomaly pattern is quite complicated, the $3 \mathrm{D}$ model can only be a semi-quantitative one. The first step was to create a starting model, constrained by the results obtained along profiles $\mathrm{AA}^{\prime}$ and $\mathrm{BB}^{\prime}$, which approximately represent the magnetic survey data. Afterwards we adjusted the model (fig. 6) by forward and inversion modeling using a combination of contoured plan and cross-sectional profiles until it provided a satisfactory fit to the data (fig. 7). A three dimensional multi-body inversion option supplements the interactive model fitting process. The basis of the method used for the inversion (of selected model parameters) is singular value decomposition of the jacobian matrix, as described by Jupp and Vozoff (1975). The residual anomalies are modeled using 3D polygonal prisms whose positions were inferred from the magnetic anomalies distribution. In particular, length, width, thickness, top and bottom depth of the prisms (table I) were controlled to find the best match to the waveform of the observed magnetic anomaly. Among three-

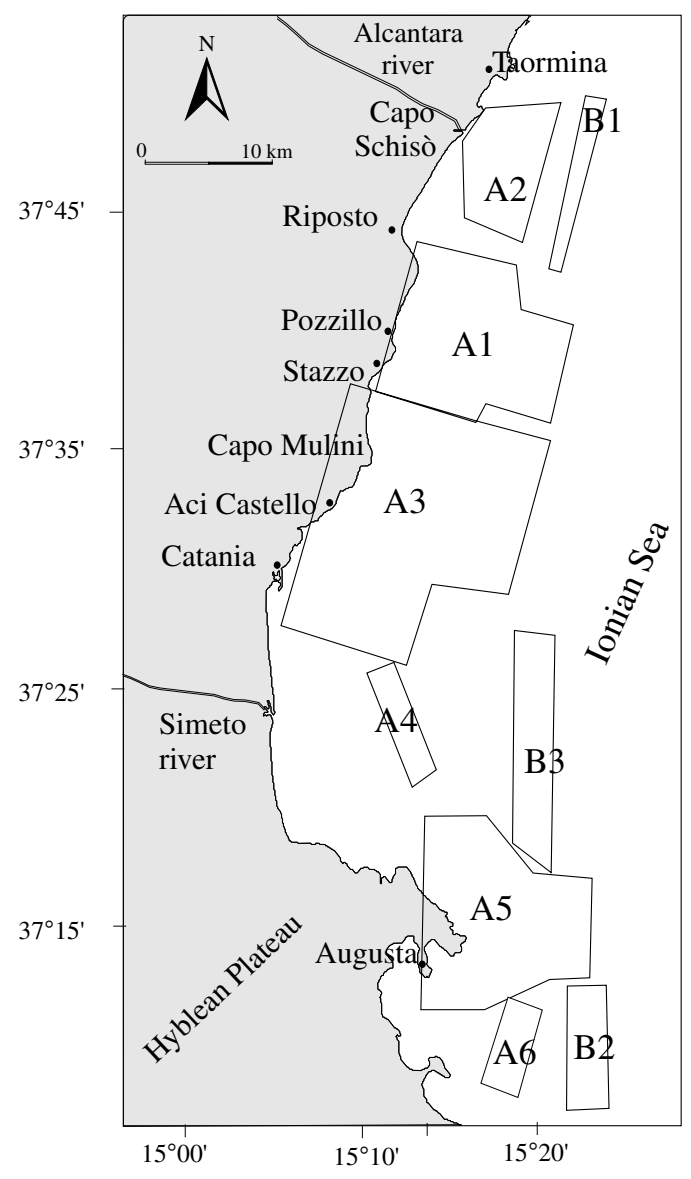

Fig. 6. 3D interpretation of the entire area. For description of bodies see text.

dimensional models obtained we choose the simplest (fig. 6) with the minimum RMS error (93 nT) between the observed (fig. 3) and calculated values (fig. 7).

\section{Discussion}

Forward models of the magnetization distribution are not unique, and imply a degree of speculation when strong constraints such as rock magnetic properties, and complete knowledge of surface geology are unavailable. However, we produced geologically meaningful 


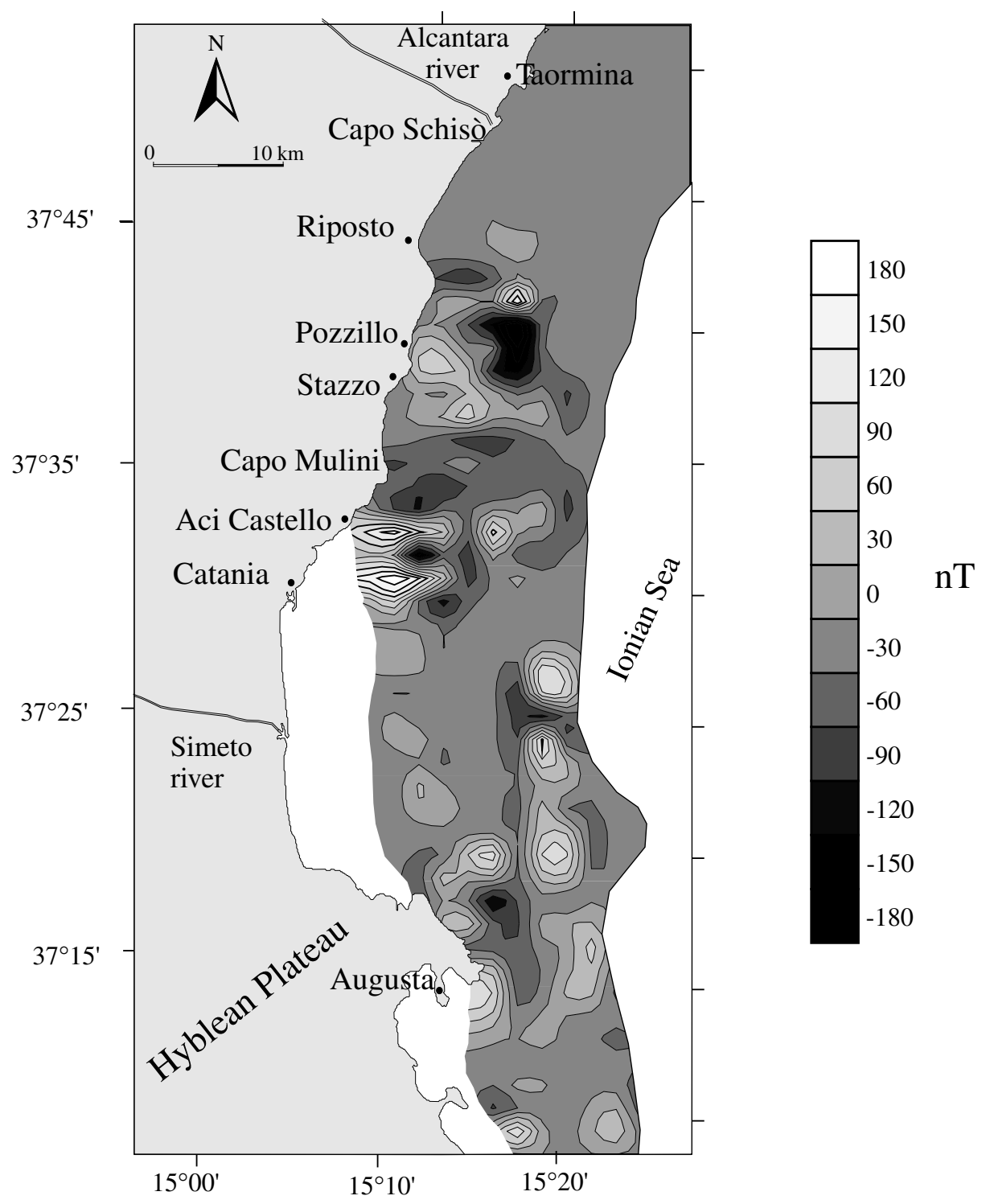

Fig. 7. Calculated anomalies corresponding to the 3D model shown in fig. 6. For magnetic properties and geometrical features of the bodies see table I.

models taking advantage of the simple shapes of the magnetic anomalies, their amplitudes, and by restricting source bodies to the upper crust. The models provide a good correlation (RMS less than $20 \mathrm{nT}$ for profiles and $100 \mathrm{nT}$ for the entire area) between observed and calculated anomalies, and also reveal a very similar geological outline to that outcropping inland.

The intense anomaly detected off the volcanic outcrops of Augusta can be interpreted as mag- 
Ciro Del Negro, Fabrizio Ferrucci and Rosalba Napoli

Table I. Magnetic properties and geometrical features of the bodies making up the 3D model shown in fig. 6 .

\begin{tabular}{llrrrrrr}
\hline \hline Body & $\begin{array}{c}\text { Remanent } \\
\text { magnetization } \\
\left(J_{\mathrm{NRM}}\right)\end{array}$ & $\begin{array}{c}\text { Susceptibility } \\
(\chi)\end{array}$ & Strike & Dip & $\begin{array}{c}\text { Maximum } \\
\text { length }\end{array}$ & $\begin{array}{c}\text { Maximum } \\
\text { width }\end{array}$ & $\begin{array}{c}\text { Mean } \\
\text { thickness }\end{array}$ \\
\hline $\mathrm{A} 1$ & $3 \mathrm{Am}^{-1}$ & 0.01 S.I. & $\mathrm{N} 15.2^{\circ} \mathrm{E}$ & $90^{\circ}$ & $13 \mathrm{~km}$ & $14 \mathrm{~km}$ & $200 \mathrm{~m}$ \\
$\mathrm{~A} 2$ & $5 \mathrm{Am}^{-1}$ & 0.034 S.I. & $\mathrm{N} 15.2^{\circ} \mathrm{E}$ & $90^{\circ}$ & $9 \mathrm{~km}$ & $6 \mathrm{~km}$ & $80 \mathrm{~m}$ \\
$\mathrm{~A} 3$ & $5 \mathrm{Am}^{-1}$ & 0.034 S.I. & $\mathrm{N} 15.2^{\circ} \mathrm{E}$ & $90^{\circ}$ & $20 \mathrm{~km}$ & $16 \mathrm{~km}$ & $150 \mathrm{~m}$ \\
$\mathrm{~A} 4$ & $3 \mathrm{Am}^{-1}$ & 0.01 S.I. & $\mathrm{N} 163^{\circ} \mathrm{E}$ & $90^{\circ}$ & $8 \mathrm{~km}$ & $2.5 \mathrm{~km}$ & $100 \mathrm{~m}$ \\
$\mathrm{~A} 5$ & $4 \mathrm{Am}^{-1}$ & 0.030 S.I. & $\mathrm{N} 3.7^{\circ} \mathrm{E}$ & $90^{\circ}$ & $15 \mathrm{~km}$ & $13 \mathrm{~km}$ & $100 \mathrm{~m}$ \\
$\mathrm{~A} 6$ & $4 \mathrm{Am}^{-1}$ & 0.030 S.I. & $\mathrm{N} 10^{\circ} \mathrm{E}$ & $90^{\circ}$ & $6 \mathrm{~km}$ & $3 \mathrm{~km}$ & $100 \mathrm{~m}$ \\
$\mathrm{~B} 1$ & $2 \mathrm{Am}^{-1}$ & 0.01 S.I. & $\mathrm{N} 20^{\circ} \mathrm{E}$ & $90^{\circ}$ & $13 \mathrm{~km}$ & $2 \mathrm{~km}$ & $100 \mathrm{~m}$ \\
$\mathrm{~B} 2$ & $2 \mathrm{Am}^{-1}$ & 0.01 S.I. & $\mathrm{N} 2^{\circ} \mathrm{E}$ & $90^{\circ}$ & $10 \mathrm{~km}$ & $4 \mathrm{~km}$ & $150 \mathrm{~m}$ \\
$\mathrm{~B} 3$ & $2 \mathrm{Am}^{-1}$ & 0.01 S.I. & $\mathrm{N} 178^{\circ} \mathrm{E}$ & $90^{\circ}$ & $20 \mathrm{~km}$ & $4 \mathrm{~km}$ & $200 \mathrm{~m}$ \\
\hline
\end{tabular}

matic intrusions (A5 and A6), which according to Zanolla et al. (1998) could have reached the seafloor surface and various sub-bottom levels by means of faults related to distension phases. In particular, A5 and A6 can be related to one or more stages of Hyblean Plateau volcanism. In this area, indeed, the volcanic activity continued intermittently up to the Pliocene and submarine and subaerial volcanic products were found along the Ionian coast from north of Augusta to the vicinity of Syracuse (outside the investigated area) both in outcrop and underground overlaid by sedimentary deposits (Carbone et al., 1982; Grasso et al., 1983). Moreover, considering that they overlap the northern faults belonging to the Malta Escarpment it is likely that these magmatic intrusions were injected along this regional discontinuity system.

Further north, two volcanic bodies, A3 and A2, stretch normally to the coast and are ascribable to Mt. Etna volcanism. The former was discovered off the lava flows outcropping at Capo Mulini. It is consistent with the presence of Etnean volcanic products (AA. VV., 1979) along the coast from Pozzillo to Catania and of volcanic bodies related to the submarine or pre-Etnean hypo-abyssal activity which are found either offshore or inland inside the Pleistocene clays forming the Etnean basement
(Gabbianelli et al., 1995). The latter is the offshore prolongation of the Alcantara lava flows, which starts from the northern flank of Mt. Etna and extends up to $4-5 \mathrm{~km}$ from the coast. It represents one of the longest Etnean lava flows.

Modeling, according to drags executed in the same oceanographic cruises (Corsaro and Pompilio, personal communication), also reveals different deposits of incoherent volcanic material, whose origin, except for the Chiancone deposit (A1) which was likely produced by a catastrophic event (Del Negro and Napoli, 2002), can be attributed to transport and settling processes offshore driven by the Simeto River (A4) or sea currents (B2 and B3).

It is worth noting that far away from the coast $(10-15 \mathrm{~km})$, volcanic bodies get thinner and volcaniclastic deposits (B1, B2 and B3), characterized by a lower magnetization and susceptibility (table I) and probably sprung from dismantling of volcanic bodies, increase. Here the magnetization contrast, essential for data inversion, diminishes because of the increase in prevalently sedimentary products whose magnetic properties are almost negligible. Therefore, modeling reliability is strongly compromised especially concerning the incoherent volcanic deposits dipped in the sedimentary basement. 


\section{Conclusions}

The magnetic anomalies observed off the eastern coast of Sicily contribute to shed light on the spatial distribution of the magnetized bodies and provide pieces of information allowing the peculiar development and geodynamic significance of magmatism in this area to be better understood. In particular, the presence of the main magnetic anomalies close to the coast reveals the strong relation between the causative bodies (basaltic rocks and volcaniclastic deposits) and the geological features encountered inland. The modeling of the investigated area, indeed, reveals a sedimentary substratum where the first volcanic products of the Hyblean and Etnean activity are inserted.

The presence of magma intrusions offshore the Hyblean Plateau in correspondence of the Malta Escarpment, besides enlarging the Hyblean area affected by volcanic activity, points out the role played by this regional discontinuity system which, producing a zone of weak disrupting crust, could have created preferential ways for magma ascents.

On the other hand, the volcanic bodies detected off the Etnean edifice, and interpreted as the first products of Etnean activity, show the spatial continuity of the volcanism affecting this area and could represent spatial transition between Hyblean and Etnean volcanism supporting the hypothesis that magma process migrated with time from south-east to north-west.

\section{Acknowledgements}

The authors are grateful to S. Tabacco, A. Di Bella, E. Spadafora for their help during the oceanographic cruises. Particular thanks are due to A. Sicali who developed the software for magnetometer management and to R. Comito for preliminary data analysis. The authors wish to thank CNR for the oceanographic ship Urania, the captain V. Lubrano and the crew which provided a valid support during data acquisition.

\section{REFERENCES}

AA. VV. (1979): Carta Geologica del Monte Etna. 1:50.000, Litografia Artistica Cartografica, Firenze.

ARISI ROTA, F. and R. FICHERA (1987): Magnetic interpretation related to geomagnetic provinces: the Italian case history, Tectonophysics, 138, 179-196.

BARberi, F., L. CivetTa, P. GASPARINI, F. INNOCENTI, R. SCANDONE and L. VILLARI (1974): Evolution of a section of the Africa-Europe plate boundary: Paleomagnetic and volcanological evidence from Sicily, Earth Planet. Sci. Lett., 22, 123-132.

BHATTACHARYYA, B.K. (1964): Magnetic anomalies due to prism-shaped bodies with arbitrary polarization, Geophysics, 29, 517-531.

Bousquet, J.C., G. GABBiAnelli, G. LANZAFAME and R. SARTORI (1998): Évolution volcanotectonique de l'Etna (Sicilie): nouvelles données de géologie marine et terrestre, Rapp. Commission Internationale pour l'Exploration Scientifique de la Mer Méditerranée, 35, 56-57.

CADY, J.W. (1980): Calculation of gravity and magnetic anomalies of finite length right polygonal prisms, Geophysics, 45, 1507-1512.

CAlvarI, S. and G. Groppelli (1996): Relevance of the Chiancone volcaniclastic deposit in the recent history of Etna volcano (Italy), J. Volcanol. Geotherm. Res., 72, 239-258.

Carbone, S., M. Grasso and F. Lentini (1982): Considerazioni sull'evoluzione geodinamica della Sicilia sud-orientale dal Cretaceo al Quaternario, Mem. Soc. Geol. It., 24, 367-386.

Chiappini, M., A. Meloni, E. Boschi, O. Faggioni, N. BEVERINI, C. CARMisciano and I. MARSON (2000): Shaded relief magnetic anomaly map of Italy and surrounding marine seas. Ann. Geofis., 43 (5), 983-989.

DEL NEGRO, C. and R. NAPOLI (2002): Ground and marine magnetic surveys of the lower eastern flank of Etna volcano (Italy), J. Volcanol. Geotherm. Res., 114 (3/4), 357-372.

Del Negro, C., F. FerruCCI and R. NAPOLI (1997): The permanent network for magnetic surveillance of Mt. Etna: changes in the geomagnetic total intensity observed in 1995, Acta Vulcanol., 9 (1), 67-72.

FAGGIONI, O., N. BEVERINI, C. CARMisciano and I. Giori (2001): A metrologic method of anomaly field amplitude reduction in undersampled geomagnetic marine surveys, Mar. Geophys. Res., 22, 63-79.

Fleming, S.W. and A.M. TREHU (1999): Crustal structure beneath the Central Oregon convergent margin from potential-field modeling: Evidence for a buried basement ridge in local contact with a seaward dipping backstop. J. Geophys. Res., 104, 20431-20447.

Gabbianelli, G., G. Lanzafame, F. Lucchini, M. POMPILIO and R. SARTORI (1995): Indagini di geologia marina alla base orientale dell'Etna, in Progetto-Etna 1993-1995, edited by F. FERRUCCI and F. INNOCENTI, CNR Gruppo Nazionale per la Vulcanologia, 79-84.

Gillot, P.Y., G. KiefFER and R. RomAno (1994): The evolution of Mount Etna in the light of potassium-argon dating, Acta Vulcanol., 5, 81-87. 
Grasso, M., F. LENTINI, A.E.M. NAIRN and L. VigLIOTTI (1983): A geological and paleomagnetic study of the Hyblean volcanic rocks, Sicily, Tectonophysics, 98, 271-295.

Grasso, M. and Z. BEN-AVRAHAM (1992): Magnetic study of the northern margin of the Hyblean Plateau, Southeastern Sicily: structural implications, Ann. Tectonicae, 6 (2), 202-213.

Hirn, A., R. Nicolich, J. Gallart, M. Laigle, L. CERNOBORI and ETNASEIS SCIENTIFIC GROUP (1997) Roots of Etna volcano in faults of great earthquakes, Earth Planet. Sci. Lett., 148, 171-191.

IAGA WORKING GROUP V-8 (1996): International Geomagnetic Reference Field, 1995 revision, Geophys. J. Int., 125, 318-321.

Ishihara, T., G.L. LeItchenkov, A.V. Golynsky, S. ALYAVDIN and P.E. O'BREIN (1999): Compilation of shipborne magnetic and gravity images crustal structure of Prydz Bay (East Antarctica). Ann. Geofis., 42 (2), 229-248.

JUPP, D.L.B and K. VozOF, (1975): Stable iterative methods for the inversion of geophysical data, Geophys. J. R. Astron. Soc., 42, 957-976.

LANZAFAME, G. and J.C. BousqueT (1997): The Maltese escarpment and its extension from Mt. Etna to the Aeolian Islands (Sicily): importance and evolution of a lithosphere discontinuity, Acta Vulcanol., 9, 113-120.

LENTINI, F. (1982): The geology of the Mt. Etna basement, Mem. Soc. Geol. It., 23, 7-25.

Monaco, C., L. Petronio and M. Romanelli (1995): Tettonica estensionale nel settore orientale del Monte Etna (Sicilia): dati morfotettonici e sismici, Studi Geologici Camerti, special issue, 2, 363-374.

PATACCA, E., P. SCANDONE, G. GIUNTA and V. LiguORI (1979): Mesozoic paleotectonic evolution of the Ragusa zone (Southeastern Sicily), Geol. Romana, 18, 331-369.

RoberTI, N. and R. SCANDONE (1975): Thermomagnetic study of basalts from South Eastern Sicily. Boll. Geofis. Teor. Appl., 67, 259-264.

ROLPH, T.C. (1992): High field intensity results from recent and historic lavas, Phys. Earth Planet. Inter., 70, 224-230.

ROSSI, S. and R. SARTORI (1981): A seismic reflection study of the external Calabrian Arc in the Northern Ionian Sea (Eastern Mediterranean), Mar. Geophys. Res., 4, 403-426.

Sartori, R., M.L. Colalongo, G. Gabbianelli, C. Bonazzi, S. CARBone, P.V. CURZI, D. EVANGElisti, M. GRASSO, F. LENTINI, S. Rossi and L. SELLI (1991): Note stratigrafiche e tettoniche sul «Rise di Messina» (Ionio nord occidentale), G. Geol., 53 (2), 49-64.

TABACCO, S. (1998): Definizione del basamento etneo sottostante il deposito vulcanoclastico del Chiancone (settore orientale dell'Etna) attraverso metodiche geologico-strutturali e geofisiche, Ph.D. Thesis, Università degli Studi di Catania, pp. 105

TAPPONNIER, P. (1977): Evolution tectonique du systeme alpin en Mediterranée: poinonnement et encresement rigide-plastique, Bull. Soc. Geol. Fr., 19, 437-460.

TAUXE, L., A.D. DeINO, A.K. BEhrenSMEYER and R. PotTs (1992): Pinning down the Brunhes/Matuyama and upper Jaramillo boundaries: As reconciliation of orbital and isotopic time scales, Earth Planet. Sci. Lett., 109, 561-572.

TORTORICI, L., P. TAPPONIER and T. WINTER (1986): Faulting during the 1783 Calabria earthquakes and tectonics of the Messina Strait, $A G U, E o s, 67,1188$.

TrIC, E., J.P. VALET, P.Y. GILLOT and I. LEMEUR (1994): Absolute paleointensities between 60 and 160 kyear BP from Mount Etna (Sicily), Phys. Earth Planet. Inter., 85, 113-129.

Zanolla, C., C. Morelli, and I. Marson (1998): The magnetic anomalies of the Mediterranean Sea (IBCMM), Boll. Geofis. Teor. Appl., 39, 1-36. 